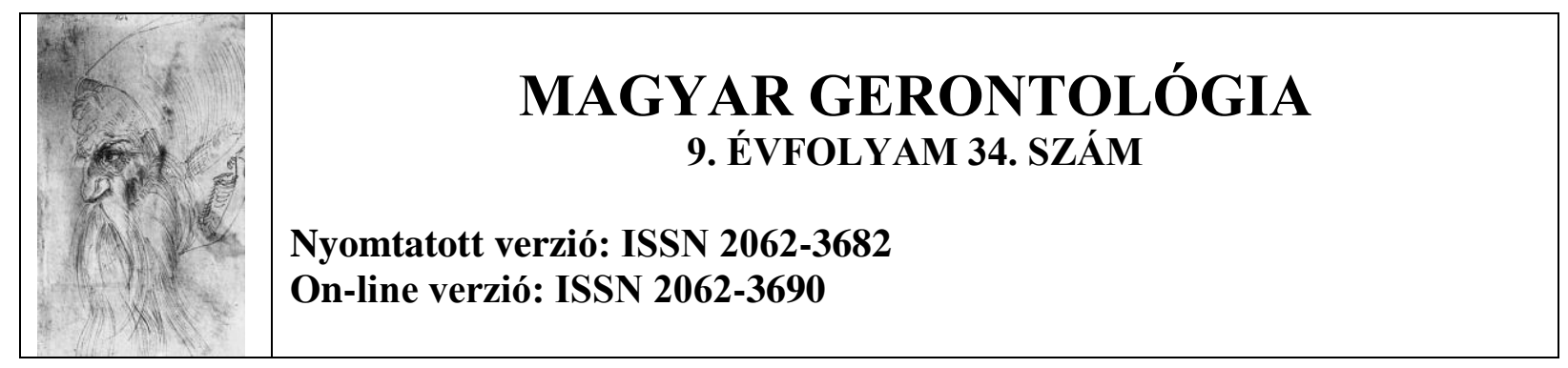

\title{
Összefoglaló
}

\section{Help wanted? Poviding and Paying for Long term Care. The Impact of Caring on Family Carers}

\author{
Az eredeti jelentést az OECD adta ki 2011 -ben. \\ Forrás: www.oecd.org/els/health-systems/47884865.pdf
}

A jelentésben az OECD a családtagok, rokonok, ismerösök, barátok, szomszédok által nem fizetésért végzett gondozási tevékenységek gazdasági és társadalmi jelentöségére hivja fel a figyelmet a szervezet.

A jelentés az OECD tagállamokban tárja fel az informális gondozás jellemzőit, különös tekintettel a gondozók helyzetére, a munka és a gondozás összeegyeztetésének kérdéseire, elöre vetítve az informális gondozás kockázatait, valamint a támogatás specifikus lehetőségeit. A tanulmány hozzá akar járulni a specifikus ágazati politikák reformjához, egyfajta iránytüként akar szolgálni a gondozók támogatásának kialakításában a munka és a gondozás összeegyeztetésében és a gondozók támogatásában, a gondozói munka elismerésében és erősítésében.

A jelentés több ország eltérő nagymintás kutatásainak másodelemzésével készült:

- Ausztria és Nagy-Britannia esetében háztartáspanel kutatás,

- Dél-Korea esetében 45 év felettiek körében végzett háztartáspanel kutatás,

- Európa esetében a SHARE,

- Az USA esetében az egészségügyi és nyugdíj kutatás (survey) adatait használták fel.

\section{Eredmények:}

Az OECD országokban minden tízedik felnőtt gondozza valamely hozzátartozóját. Ez a gondozás nem fizetett tevékenység és a tevékenység köre általában az ADL jellegű személyes gondozásra terjed ki. 
Az országok között nem lehet tiszta földrajzi összefüggéseket levonni. Az informális (sok helyen a tanulmány unpaid néven említi) gondozás átlagosan 8 és 18\%-át érinti a populációnak, tehát ennyi embert lehet gondozóként definiálni az adatbázisok szerint. Legnagyobb arányban Olasz- és Spanyolországban, legalacsonyabb arányban Görögországban és Dániában, valamint Svédországban találunk gondozókat. A tanulmány megjegyzi, hogy általánosságban eléggé eltérő definitív háttere van az informális gondozásnak, s ez is okozhatja a statisztikai szórást.

A tevékenység szélesebb értelmezése esetében (IADL) azt lehet látni, hogy minden harmadik 50 év feletti informális gondozást végez. Dél - Európa kivételével mindenhol az IADL aktivitásokban való segédkezés jelenti a gondozási tevékenységek jelentősebb részét.

A gondozók többségében nők, de a férfiak aránya a gondozók életkorának arányában növekszik. Az adatok szerint a 75 év feletti korosztályban egyes országokban relatíve több férfi gondozót találunk, mint hölgyet. A 16 vizsgált országot összevetve a gondozók közel 2/3-a ötven év feletti nő volt. 75 év felett azonban csökken a gondozói aktivitás, mely vélhetően a romló egészségi állapottal mutat összefüggést.

\section{Módszertani megjegyzések:}

- A gondozók sok esetben nem definiálják magukat gondozóként

- A fogalomrendszer nem egységes a gondozó definíciójával kapcsolatban

- Általánosságban gondozóként határozzák meg azt, aki heti egy órát, vagy annál többet gondozási tevékenységet végez a háztartáson belül, vagy kívül. Ez a munka nem fizetett.

- UK: segítségnyújtás azoknak, akik betegek, fogyatékkal élnek, vagy idősek (szélesebb értelmezés)

- Több helyen az ötven év feletti gondozókra helyezik a hangsúlyt

- UK, Ausztrália: a gondozók jelentős hányada (75-80\%) 45 éves, vagy idősebb. Az 50 - 64 év közötti gondozók esetében a munka világából való kiszorulás kockázatait elemezték - különösen az idő elötti nyugdíjazás tekintetében.

Barát, szomszéd átlagosan a gondozók 18\%-ában, rokon szintén 18\%-ban található a gondozók között. A férfi gondozók szinte kizárólag saját párjukat gondozzák.

\section{Gondozási idő}

Általánosságban a gondozók 50\%-a heti 10 óránál kevesebb időben végzi tevékenységét. Az észak-európai országokban és Svájcban relatíve alacsony a komoly - heti 20 órát meghaladó 
gondozási terhe a gondozóknak (20\%), melyet a tanulmány a formális szolgáltatások jobb hozzáférhetőségével magyaráz.

A dél - európai országokban magasabb az intenzív gondozást végzők aránya, csakúgy, mint Csehországban és Lengyelországban (30\% feletti), legmagasabb értéket a spanyol $50 \%$ feletti ráta, illetve Dél-Korea $60 \%$ feletti intenzív gondozási rátája képviseli.

A gondozási ráfordítást alapjában meghatározza a gondozottak egészségi állapota. A kutatások adatai szerint az ötven év felettiek negyede igényel(ne) gondozói segítséget alapvető tevékenységek elvégzéséhez (ADL). A gondozás igényét ezen kívül még az elérhető formális szolgáltatások is befolyásolhatják (azok színvonala, hozzáférhetösége, megfelelősége). Az alapvetően magukat ellátni nem képes csoport tagjai közül többen igényelnek segítséget Csehországban, Írországban és a dél - európai államokban.

\section{Gondozás és munka összeegyeztetése}

A gondozás rontja a munkaerőpiacon való részvétel esélyét. A gondozók átlag 50\%-kal többen vállalnák az otthon maradást, mint a hasonló korú gondozást nem végzők.

A foglalkoztatási rátát befolyásolja a korosztály átlagos részvételi esélye a munkaerőpiacon, valamint a rugalmas foglalkoztatási lehetőségek elérésének esélye is. Átlagosan kisebb a foglalkoztatásból való kiszorulás kockázata az északi országokban és nagyobb DélEurópában, valamint Lengyelországban (hazánkat nem érinti az elemzés, abban az évben nem volt részese a SHARE-nek). A déli országokban a gondozók több mint 40\%-a otthon tartózkodik, nem dolgozik. Másutt (pl. Ausztria, Olaszország) a gondozók nagy része maga is időskorú, s ezért alacsony a munkaerőpiaci részvételi arányuk. A vizsgálat nem mutatott statisztikai összefüggést a gondozók képzettsége és munkaerö-piaci részvételének rátája között.

A munkaerő-piaci részvétel nem jelent ez esetben automatikusan alacsonyabb rátát a munkaerö-piacon, sokkal inkább a teljes munkaidőben foglalkoztatottak körében lehet csökkentést tapasztalni. Átlagosan heti két órával dolgoznak kevesebbet azok, akik gondoznak is valakit. Ausztráliában átlag heti három óra ez az adat.

A foglalkoztatás esélyét más tényezők is befolyásolják:

- A gondozási támogatások általában növelik a munkaerő-piacról való kivonulás esélyét,

- a helyi munkanélküli ráta is befolyásolhatja a gondozást végzők döntését. 
Ha az alacsonyabb végzettségüeknek nehezebb a munkavállalás, akkor körükben magasabb lehet a gondozást vállalók aránya, s így erőteljesebbé válnak a gondozásnak szociális és gazdasági kényszerei és hatásai.

A gondozási idő szoros összefüggést mutat a munkaerő-piaci részvétellel. Az intenzív gondozást végzők (heti 20 óra és felette) valamint a gondozottal együtt élők esetében erősebb a munkaerő-piacról való kiszorulás. Ezt befolyásolhatja a formális szolgáltatások elérhetősége is. A munkaerő-piacról való kiszorulás pedig sok országban a gondozó és gondozott szociális rászorultságát erősíti meg.

A munka és a gondozás összeegyeztetésében a nyugat és észak európai foglalkoztatási politikák kedvezően hatnak, míg délen erősebb a gondozás miatti kiszorulás esélye ezen okokból is.

Általánosságban látható, hogy a munkából való kiszorulás, kivonulás enyhébb gondozási szükséglet esetében kevésbé hátrányos, míg 20 óra feletti heti gondozás esetében meghatározóan befolyásolja a munkaerő-piaci részvételt. A munkaerő-piaci részvétel csökkenése magával hozza a háztartás bevételeinek csökkenését, a társadalmi tőke leépülését, valamint a munka-készségek elveszítését. A munkavállalói korú gondozók szegénységkockázata növekszik, mely komoly hatást gyakorol a gondozóra, s így a gondozott életminőségére is. A munkából való kiszorulás elsősorban a nőket érinti, a férfiak inkább a részmunkaidőt választják, ha gondozniuk kell.

\section{A gondozók mentális egészsége}

Az izoláció, a gondozás terhei, a támogatás hiánya növeli a pszichológiai distressz kockázatát. A pszichés problémákkal küzdő gondozók aránya az OECD országokban átlagosan 20\%-kal magasabb, mint a hasonló korú gondozást nem végzők esetében. A mentális problémával élő gondozók aránya Görögországban a legmagasabb, Svájcban a legalacsonyabb.

A mentális problémák szignifikáns összefüggést mutatnak a gondozás intenzitásával. Azon országokban, ahol a gondozók között magasabb arányban találunk férfiakat, ott a mentális problémák gyakorisága is magasabb a férfi gondozók körében. A mentális problémák prevalenciája az átlaghoz képes magasabb Ausztráliában, az USA-ban, valamint Koreában. Itt $70-80 \%$-kal is meghaladja a hasonló korú átlagpopuláció mért értékeit. Ezeket az értékeket inkább az intenzív gondozást végzőknél lehet észlelni, a kevesebb gondozást végzők esetében alacsonyabb rátákkal találkozunk. Aránylag kevés megbízható követéses 
kutatás hiányában nem lehet pontos információkat mondani arról, hogy ezek a gondozók milyen mentális állapotban voltak korábban, a gondozást megelőző időszakokban.

A kutatások szerint a gondozási díj támogatás alapjában nem csökkenti a mentális betegség előfordulási esélyét a gondozók körében, tehát más célzott segítségre van szüksége a gondozóknak. A gondozóval való együttélés viszont statisztikai korrelációt mutat a mentális problémák arányának növekedésével.

\section{Gondozás és szociális hátrány}

Korábban említettük, hogy az intenzíven gondozók (heti 20 óra és több) nagyobb arányban maradnak ki a munkaerő-piacról. További szociális kockázatokat is hordoz az informális gondozás. Az intenzív gondozók általában idősebbek, alacsonyabb végzettségűek, és szegényebbek, mint a kevesebb gondozást végzők.

A 75 év feletti gondozók körében például kétszer annyi intenzíven gondozót találunk, mint az 50-64 éves korosztályban. Az intenzív gondozás általában a (házas)társ által végzett tevékenységeket jelenti (UK: 70\%; CEU 42,3\%; EU: 50\%).

Az intenzívebb gondozást végzők sokkal nehezebb szociális helyzetben vannak, mint a nem gondozó kortársaik. 60\%-uk tartozik az alsó két jövedelmi ötödbe (a kevesebbet gondozók esetében ez az arány 40\%). A szegénységi ráta kétszerese a nem intenzíven gondozókénak. Az angolszász és dél-európai országokban különösen igaz ez az állítás, ahol az intenzíven gondozók 40\%-a a szegénységi küszöb alatt él, szemben a skandináv országokkal, ahol ez az arány $10 \%$.

\section{Konklúziók}

Fö csoportok a célzott intézkedések szempontjából:

- Külön élő, de munkavállalói korú gondozók

- Intenzíven gondozók

- Közös háztartásban élő gondozók

- Emelni szükséges az informális gondozás támogatását. Rugalmas foglalkoztatási politikával segíteni szükséges a gondozás és a munka összeegyeztetését, valamint a gondozók munkából való kilépését követően a munka világába történő visszatérését. Támogató programokkal kell segíteni a célcsoport elérését. 
- Segíteni kell a gondozásra való felkészülést célcsoport specifikus támogatásokkal. Különösen fontosak a gondozók mentálhigiénés, mentális egészségét támogató szolgáltatásai, illetve a különböző támogató szolgáltatások, melyek az informális gondozót tehermentesítik.

- Foglalkozni szükséges a gondozási díjak és juttatások rendszerével, hogy ne vezessen a gondozó és a gondozott elszegényedéséhez maga a gondozás.

- Mindenképp meg kell erősíteni a formális szolgáltatásokat, mivel azon országokban, ahol ezek megfelelően hozzáférhetők balanszírozhatják az informális gondozók terheit is.

- Különös jelentősége van a formális és informális gondozás kombinációinak, egymást kiegészítő és segítő rendszereinek fejlesztésének.

\section{Fordította és az összefoglalót írta:}

Patyán László

Főiskolai docens

Debreceni Egyetem Egészségügyi Kar

Gerontológia tanszék 